\title{
Nest stolen: the first observation of nest predation by an invasive exotic marmoset (Callithrix penicillata) in an agricultural mosaic
}

\author{
Eduardo Roberto Alexandrino ${ }^{1,2}$, Daniela Tomasio Apolinario da Luz ${ }^{1,3}$, \\ Erica Vanessa Maggiorini ${ }^{1,3}$ \& Katia Maria Paschoaletto Micchi de Barros Ferraz, ${ }^{1,4}$ \\ ${ }^{1}$ Departamento de Ciências Florestais, Escola Superior de Agricultura “Luiz de Queiroz”, \\ Universidade de São Paulo - USP, CEP 13418-900, Piracicaba, SP, Brasil \\ ${ }^{2}$ Programa de Pós-Graduação em Ecologia Aplicada, Escola Superior de Agricultura "Luiz de Queiroz", \\ Universidade de São Paulo - USP, Piracicaba, SP, Brasil \\ ${ }^{3}$ Programa de Pós-Graduação em Recursos Florestais, Escola Superior de Agricultura "Luiz de Queiroz”, \\ Universidade de São Paulo - USP, Piracicaba, SP, Brasil \\ ${ }^{4}$ Corresponding author: Katia Maria Paschoaletto Micchi de Barros Ferraz, e-mail: katia.ferraz@usp.br
}

ALEXANDRINO, E.R., LUZ, D.T.A., MAGGIORINI, E.V. \& FERRAZ, K.M.P.M.B. Nest stolen: the first observation of nest predation by an invasive exotic marmoset (Callithrix penicillata) in an agricultural mosaic. Biota Neotrop. 12(2): http://www.biotaneotropica.org.br/v12n2/en/abstract?short-communication+bn01612022012

\begin{abstract}
Invasive exotic species can negatively impact local biodiversity. We present here a report of a nest predation of an endemic bird species, variable oriole (Icterus pyrrhopterus) by the introduced black-tufted marmoset (Callithrix penicillata) in an agricultural landscape highly disturbed by human activities. Two nestlings were predated, by adults of the introduced marmoset during two alternate days. Antipredator behavior and vocal mimicry were observed in variable oriole, while copulation was observed in black-tufted marmoset during the predation. The use of mobbing against predators by I. pyrrhopterus was observed and it is described here by the first time. The potential impact of the introduced marmosets to local biodiversity is discussed.

Keywords: invasive alien species, birds, mobbing behaviour, nest predation, nest defense.
\end{abstract}

ALEXANDRINO, E.R., LUZ, D.T.A., MAGGIORINI, E.V. \& FERRAZ, K.M.P.M.B. Saque a ninho: primeira observação de predação de ninho por um sagui exótico invasor (Callithrix penicillata) em um mosaico agrícola. Biota Neotrop. 12(2): http://www.biotaneotropica.org.br/v12n2/pt/abstract?short-communication+bn01612022012

Resumo: Espécies exóticas invasoras podem impactar negativamente a biodiversidade de um local. Nós descrevemos aqui um relato de predação a um ninho de uma espécie de ave endêmica, inhapim (Icterus pyrrhopterus) pelo sagüi-de-tufo-preto (Callithrix penicillata), espécie exótica invasora, em uma paisagem agrícola altamente impactada pelas atividades humanas. Dois ninhegos foram predados por adultos de sagüi em dois dias alternados. Durante a predação foram observados comportamento anti-predatório e imitações vocais pelo inhapim, e atividade de cópula do sagüis-de-tufo-preto. Descrevemos também o primeiro relato do uso de mobbing por I. pyrrhopterus contra predadores. O impacto potencial dos sagüis introduzidos na biodiversidade local é discutido.

Palavras-chave: espécies invasoras, aves, interação interespecífica, mobbing, predação de ninhos, defesa de ninho. 


\section{Introduction}

Biological invasions by exotic species are considered one of the greatest threats to biodiversity driving losses in the biological diversity of native species and populations (Lodge 1993, Vitousek et al. 1997a, b, McGeoch et al. 2010). The enormous impact of non-native species is often irreversible, especially when invaders are biotic disturbance agents, altering the ecosystem structure and function (Vitousek 1990, Mack \& D'Antonio 1998). The clear effects on ecosystem-level properties are related to differences in resource acquisition and/or use efficiency, the alteration of trophic structure of the area invaded, or the alteration of disturbance frequency and/ or intensity (Vitousek 1990, Crooks \& Soulé 1999).

Abundant mesopredators can negatively affect avian community by nest predation (Rogers \& Caro 1998, Crooks \& Soulé 1999, Galetti et al. 2009). Nest predation is considered the main cause of nest failure in tropical birds (Skutch 1985, Wilcove 1985, Roper \& Goldstein 1997), being more frequent in fragmented and urban areas (Wilcove 1985, Robinson et al. 1995). Nest predation may increase with fragmentation (Robinson et al. 1995) and human density (Jokimaki \& Huhta 2000, Thorington \& Bowman 2003).

The presence of introduced marmosets in southeastern Brazil has been reported as a potential threat to local biodiversity. Marmosets could compete with other primate species and birds for resources (Negrão \& Valladares-Pádua 2006, Ruiz-Miranda et al. 2006, LyraNeves et al. 2007), depredate birds and eggs (Lyra-Neves et al. 2007, Begotti \& Landesmann 2008, Galetti et al. 2009), hybridize with conspecifics (Alonso et al. 1987, Passamani et al. 1997, Nunes 2006, Ruiz-Miranda et al. 2006, Begotti \& Landesmann 2008), and be vehicles for the introduction of new pathogens (Sales et al. 2010).

In this context, we described here the first well documented nest predation event by an introduced and opportunistic species, the black-tufted marmoset (Callithrix penicillata E. Geoffroy 1812), on a native bird species, the variable oriole (Icterus pyrrhopterus Vieillot 1819) having a highly disturbed agricultural mosaic as a background. The marmoset inhabits mature gallery forests of the Brazilian Central Plateau, with a distribution ranging from the states of Maranhão and southwest Piauí to the north of São Paulo, including most of Bahia, Minas Gerais and Goiás (Vivo 1991, Rylands et al. 1993), but nowadays, the species is widely distributed in the whole southeastern Brazil. The species are able to live in the most unfavorable and anthropogenic environments possibly due to their general habitat requirements, large food niche breadth, and high capacity to adapt to disturbed areas. Their diet includes insects, spiders, small vertebrates, bird's eggs, fruits, seeds and tree exudates (Nowak \& Paradiso 1983, Miranda \& Faria 2001, Vilela \& Faria 2002, Mamede \& Alho 2008). The distribution of food resources can influence their home range size (Castro 2003), reaching up 18.5 ha (Miranda \& Faria 2001). The threat of niche overlapping and competition for resources between C. penicilatta and Callithrix aurita (E. Geoffroy 1812) (endemic species from semideciduous forest) and Leontopithecus rosalia (Linnaeus 1766) (the reintroduced endangered golden lion tamarin) have been reported (Stevenson \& Rylands 1988, Ruiz-Miranda et al. 2006). The abundance of introduced marmosets in southeastern Brazil and its great potential for adaptation and colonization of new habitats have triggered a number of questions about its impact on local biodiversity.

\section{Material and Methods}

We observed a predation event that occurred in a tropical garden close to a university building in the "Luiz de Queiroz" campus (Piracicaba, São Paulo, Southeastern Brazil) (Figure 1). The area is characterized as an agricultural mosaic formed by urban areas, pasture, experimental plantations of annual and perennial crops, reforestation's areas and forest remnants (Sparovek 1993). The entire predation event lasted three consecutive days (April 2011), but the attacks were observed only in the first and in the third day. The event was observed with binoculars, documented by photos and video, and then transcribed in detail.

\section{Results and Discussion}

Two nestlings (around 5-8 days old) were depredated, one per each day, by adults of introduced marmoset during two alternate days. The day before the first attack, a nest of I. pyrrhopterus with three nestlings was found on a palm leaf which broke away from the canopy ( $15 \mathrm{~m}$ ) and fell down over the bushes $(2.5 \mathrm{~m})$. Adults of $I$. pyrrhopterus stayed with the nestlings, feeding them and actively defending the territory even after nest had fallen. The day after the fall, we observed the first predation on the nest by an adult of $C$. penicillata (about 4 $\mathrm{pm}$ ), while four other individuals (two adults and two infants) were also present. An adult marmoset ate the nestling without sharing it with the rest of the group. Although this group is often seen foraging together every day in the afternoon on the same site, this was the first time that predation of nestlings was observed and reported on campus. Two days later, we observed a new attack to the same nest by the same group (Figure 2). An adult female approached, grabbed the second nestling, while others remained a few meters away. After the capture, the predator moved away from the nest with the prey in its hands and ate it almost completely (head, wings and breast) (Figure 3) sharing only a small part with a male which compete for food with her. While the female was still eating, we observed the male searching for a new prey in the nest that was empty. After finishing, the male approached and copulated with the female. The copulation lasted just a few seconds. At the end, the marmosets moved away. As the nest was empty after the second predation observed we assumed the third nestling was depredated one day before.

The antipredator behavior of I. pyrrhopterus was documented only on the last predation. During the whole predation event (approaching, capture and feeding) the parents remained very close to the nest vocalizing intensively while the marmosets were in the site. We observed alarm calls and vocal mimicry from both I. pyrrhopterus. Species such as campo flicker (Colaptes campestris Vieillot 1818), roadside hawk (Rupornis magnirostris Gmelin 1788), sapphire-spangled emerald (Amazilia lactea Lesson 1832), boat-billed flycatcher (Megarynchus pitangua Linnaeus 1766), great kiskadee (Pitangus sulphuratus Linnaeus 1766) and smooth-billed ani (Crotophaga ani Linnaeus 1758) were imitated by parents. All mimics lasted less than one second, and were mixed with sharp notes that are common on the I. pyrrhopterus. They also produced a sequence of calls of two flock species of Psitacidae, yellow-chevroned parakeet (Brotogeris chiriri Vieillot 1818) and blue-winged parrotlet (Forpus xanthopterygius Spix 1824). These calls indeed attracted species that were mimicked, like sapphirespangled emerald (Amazilia lactea), but also non-mimicked such as bananaquit (Coeraba flaveola Linnaeus 1758) and pale-breasted thrush (Turdus leucomelas Vieillot 1818).

This mimicry behavior has been previously described for I. cayannensis in Argentina by Fraga (1987). Although, vocal mimicry was not observe during a nest predation event, Fraga (1987) inferred that the behavior might reduce predation risk (Morton 1976, Morse 1977). Our observation is consistent with this supposition and we believe that I. pyrrhopterus mimics started mobbing (Altmann 1956, Wilson 1975, Krams et al. 2009) the predator. Vocal mimics were only performed while the marmosets remained near the nest and when the depredation began. In all other situations only the species-specific 
alarm calls were performed. Aggressive flights at marmosets, but without physical contact, followed by vocal bass notes, were also observed. Defense of the nest from predator is also reported in other species (Knight \& Temple 1986, Breitwisch 1988, Arnold 2000, Hogstad 2004, Lyra-Neves et al. 2007).

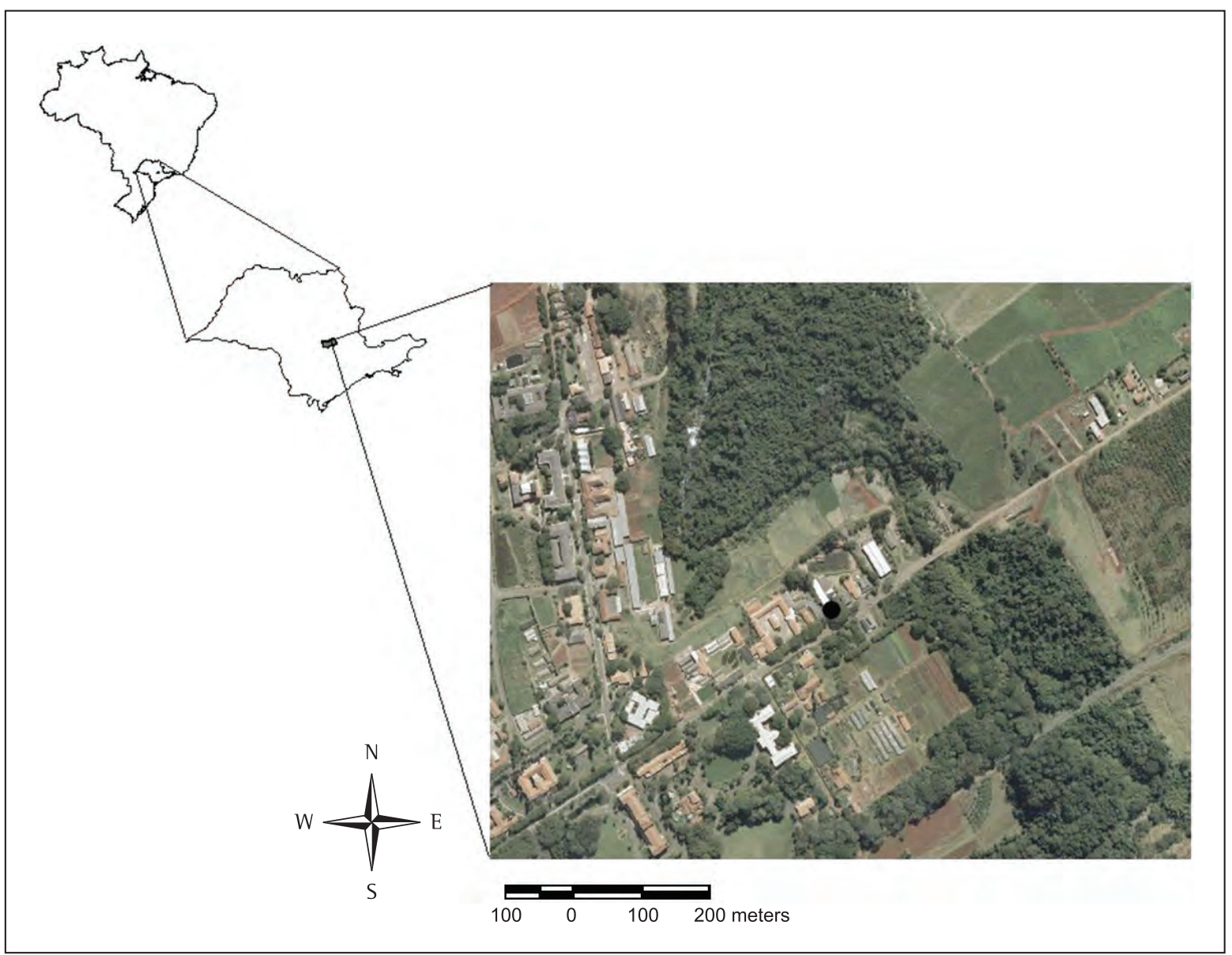

Figure 1. Predation site in Piracicaba, São Paulo state, Brazil.

Figura 1. Local da predação em Piracicaba, Estado de São Paulo, Brasil.

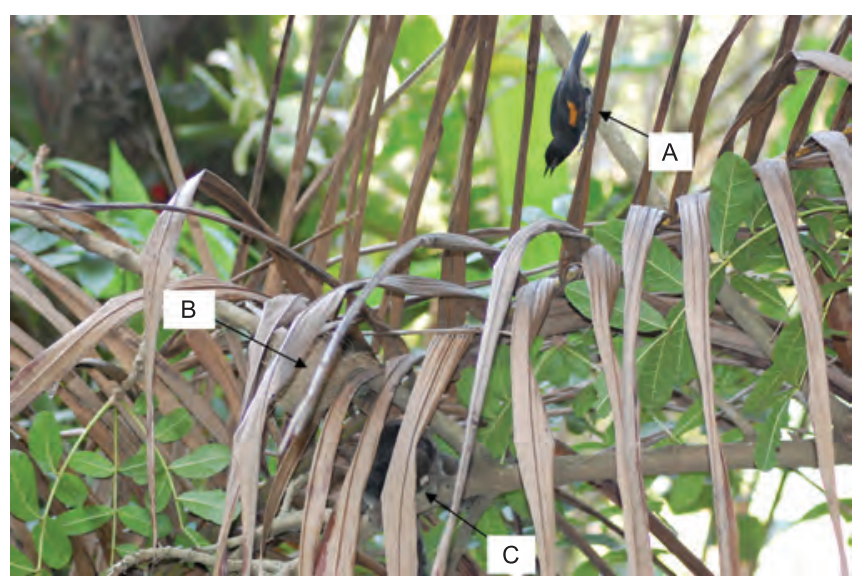

Figure 2. The parental of variable oriole (Icterus pyrrhopterus) (a) close to the nest (b) before attack predation by the black-tufted marmoset (Callithrix penicillata) (c).

Figura 2. Parental de inhapim (Icterus pyrrhopterus) (a) próximo do ninho (b) antes da predação feita pelo sagüi-de-tufo-preto (Callithrix penicillata) (c).



Figure 3. The black-tufted marmoset (Callithrix penicillata) predating a nestling of variable oriole (Icterus pyrrhopterus).

Figura 3. Sagüi-de-tufo-preto (Callithrix penicillata) predando um ninhego de inhapim (Icterus pyrrhopterus). 
Despite being a single-event, this predation report may illustrate the possible impact of this invasive species on native bird species. Investigation about its real impact as the possible impact mitigation actions should be proposed and implemented. Our observation of nest predation suggests that exotic marmosets have the potencial to act as predators of native birds and, thus, may harm local avian populations.

\section{Acknowledgements}

We are grateful to the Forest Science Department, "Luiz de Queiroz" College of Agriculture, University of São Paulo.

\section{References}

ALONSO, C., FARIA, D.S., LANGGUTH, A. \& SANTEE, D.F. 1987. Variação da pelagem na área de intergradação entre Callithrix jacchus e Callithrix penicillata. Braz. J. Biol. 47:465-470.

ALTMANN, S.A. 1956. Avian mobbing behavior and predator recognition. Condor 58(4):241-253. http://dx.doi.org/10.2307/1364703

ARNOLD, K.E. 2000. Group mobbing behaviour and nest defence in a cooperatively breeding Australian bird. Ethol. 106(5):385-393.

BEGOTTI, R.A. \& LANDESMANN, L.F. 2008. Predação de ninhos por um grupo híbrido de sagüis (Callithrix jacchus/penicillata) introduzidos em área urbana: implicações para a estrutura da comunidade. Neotrop. Primates 15(1):28-29.

BREITWISCH, R. 1988. Sex-differences in defense of eggs and nestling by northern mockingbirds, Mimus polyglottos. Anim. Behav. 36:62-72. http://dx.doi.org/10.1016/S0003-3472(88)80250-1

CASTRO, C.S.S. 2003. Tamanho da área de vida e padrão de uso do espaço em grupos de sagüis, Callithrix jacchus (Linnaeus) (Primates, Callitrichidae). Rev. Bras. Zool. 20(1):91-96.

CROOKS, K. \& SOULÉ, M.E. 1999. Mesopredator release and avifaunal extinctions in a fragmented system. Nature 400:563-566.

FRAGA, R.M. 1987. Vocal mimicry in the Epaulet Oriole. Condor 89(1):133137. http://dx.doi.org/10.2307/1368767

GALETTI, M., BOVENDORP, R.S., FADINI, R.F., GUSSONI, C.O.A., RODRIGUES, M., ALVAREZ, A.D., GUIMARÃES JUNIOR, P.R. \& ALVES, K. 2009. Hyper abundant mesopredators and bird extinction in an Atlantic forest island. Zoologia 26(2):288-298.

HOGSTAD, O. 2004. Nest defence strategies in the Fieldfare Turdus pilaris: the responses on an avian and a mammalian predator. Ardea 92(1):79-84.

JOKIMAKI, J. \& HUHTA, E. 2000. Artificial nest predation and abundance of birds along an urban gradient. Condor 102(4):838-847. http://dx.doi. org/10.1650/0010-5422(2000)102[0838:ANPAAO]2.0.CO;2

KNIGHT, R.L. \& TEMPLE, S.A. 1986. Nest defence in the American goldfinch. Anim. Behav. 34(3): 887-897.

KRAMS, I., BERZINS, A. \& KRAMA, T. 2009. Group effect in nest defence behaviour of breeding pied flycatchers, Ficedula hypoleuca. Anim. Behav. 77:513-517.

LODGE, D.M. 1993. Biological invasions: lessons for ecology. Trends Ecol. Evol. 8(4):133-136.

LYRA-NEVES, R.M., OLIVEIRA, M.A.B., TELINO-JUNIOR, W.R. \& SANTOS, E.M. 2007. Comportamentos interespecíficos entre Callithrix jacchus (Linnaeus) (Primates, Callitrichidae) e algumas aves de Mata Atlântica, Pernambuco, Brasil. Rev. Bras. Zool. 24(3):709-716.

MACK, M.C. \& D’ANTONIO, C.M. 1998. Impacts of biological invasions on disturbance regimes. Trends Ecol. Evol. 13(5):195-198.

MAMEDE, S.B. \& ALHO, C.J.R. 2008. Impressions of the cerrado \& pantanal a guide for the observation of the non - flying mammals. 2nd ed. UFMS, Campo Grande.

McGEOCH, M.A., BUTCHART, S.H.M., SPEAR, D., MARAIS, E., KLEYNHANS, E.J., SYMES, A., CHANSON, J. \& HOFFMANN, M. 2010. Global indicators of biological invasion: species numbers, biodiversity impact and policy responses. Divers. Distrib. 16(1):95-108.
MIRANDA, G.H.B. \& FARIA, D.S. 2001. Ecological aspects of blackpincelled marmoset (Callithrix penicillata) in the cerradão and dense cerrado of the Brazilian Central Plateau. Braz. J. Biol. 61(3):397-404.

MORSE, D.H. 1977. Feeding behavior and predator avoidance in heterospecific groups. BioScience 27(5):332-339. http://dx.doi.org/10.2307/1297632

MORTON, E.S. 1976. Vocal mimicry in the Thick-Billed Euphonia. Wilson Bull. 88(3):485-487.

NEGRÃO, M.F.F. \& VALLADARES-PÁDUA, C. 2006. Registros de mamíferos de maior porte na Reserva Florestal do Morro Grande, São Paulo. Biota Neotrop. 6(2): http://www.biotaneotropica.org.br/v6n2/pt/ abstract?article+bn00806022006 (último acesso em 13/10/2011). http:// dx.doi.org/10.1590/S1676-06032006000200006

NOWAK, R.M. \& PARADISO, J.L. 1983. Walker's mammals of the world. 4th ed. John Hopkins University Press, Baltimore.

NUNES, A.M. 2006. Ecologia cognitiva e forrageio social em híbridos de Callithrix penicillata $x$ Callithrix jacchus (Primates: Cebidae: Callitrichinae) introduzidos na ilha de Santa Catarina. Dissertação de mestrado, Pontifícia Universidade Católica do Rio Grande do Sul, Porto Alegre.

PASSAMANI, M., AGUIAR, L.M.S., MACHADO, R.B. \& FIGUEIREDO, E. 1997. Hybridization between Callithrix geoffroyi and C. penicillata in Southeastern Minas Gerais, Brasil. Neotrop. Primates 5(1):9-10.

ROBINSON, S.K., THOMPSON III, F.R., DONOVAN, T.M., WHITEHEAD, D.R. \& FAABORG, J. 1995. Regional forest fragmentation and the nesting success of migratory birds. Science 267:1987-1990.

ROGERS, C.M. \& CARO, M.J. 1998. Song sparrows, top carnivores and nest predation: a test of the mesopredator release hypothesis. Oecologia 116(12):227-233. http://dx.doi.org/10.1007/s004420050583

ROPER, J.J. \& GOLDSTEIN, R.R. 1997. A test of the Skutch Hypothesis: does activity at nests increase nest predation risk? J. Avian. Biol. 28(2):111116.

RUIZ-MIRANDA, C.R., AFFONSO, A.G., MORAIS, M.M., VERONA, C.E., MARTINS, A. \& BECK, B. 2006. Behavioral and ecological interactions between reintroduced golden lion tamarins (Leontopithecus rosalia Linnaeus, 1766) and introduced marmosets (Callithrix spp Linnaeus, 1758) in Brazil's Atlantic Coast Forest fragments. Braz. Arch. Biol. Technol. 49(1):99-109.

RYLANDS, A.B., COIMBRA-FILHO, A.F. \& MITTER-MIEIER, R.A. 1993. Systematics, geographic distribution, and some notes on the conservation status of the Callitrichidae. In Marmosets and tamarins: systematics, behaviour, and ecology (A.B. Rylands, ed.). Oxford University Press, Oxford, p.11-77.

SALES, I.S., RUIZ-MIRANDA, C.R. \& SANTOS, C.P. 2010. Helminths found in marmosets (Callithrix penicillata and Callithrix jacchus) introduced to the region of occurrence of golden lion tamarins (Leontopithecus rosalia) in Brazil. Vet. Parasitol. 171(1-2):123-129.

SKUTCH, A.F. 1985. Clutch size, nesting success, and predation on nests of neotropical birds, reviewed. Ornithol. Monogr. 36:575-594.

SPAROVEK, G. 1993. Avaliação das terras do campus "Luiz de Queiroz": aspectos físicos, capacidade de uso, uso da terra, adequação de uso e aptidão. ESALQ, Departamento de Solos, Piracicaba.

STEVENSON, M.F. \& RYLANDS, A.B. 1988. The marmosets, genus Callithrix. In Ecology and Behavior of Neotropical Primates (R.A. Mittermeier, A.B. Rylands, A.F. Coimbra-Filho \& G.A.B. Fonseca, eds.). World Wildlife Fund, Washington, v.2.

THORINGTON, K.K. \& BOWMAN, R. 2003. Predation rate on artificial nests increases with human housing density in suburban habitats. Ecography 26(3):188-196.

VILELA, L.S. \& FARIA, D.S. 2002. Dieta do Callithrix penicillata (Primates, Callitrichidae) em áreas do cerrado no Distrito Federal, Brasil. Neotrop. Primates 10(1):17-20.

VITOUSEK, P.M. 1990. Biological invasions and ecosystem processes: towards an integration of population biology and ecosystem studies. Oikos 57(1):7-13. http://dx.doi.org/10.2307/3565731 
VITOUSEK, P.M., D'ANTONIO, C.M., LOOPE, L.L., REJMANEK, M. \& WESTBROOKS, R.1997a. Introduced species: a significant component of human caused global change. New Zeal. J Ecol. 21(1):1-16.

VITOUSEK, P.M., MOONEY, H.A., LUBCHENCO, J. \& MELILLO, J.M. 1997b. Human domination of Earth's ecosystems Science 277:494-499. http://dx.doi.org/10.1126/science.277.5325.494
VIVO, M.1991. Taxonomia de Callithrix Erxleben, 1777 (Callitrichidae, Primates). Fundação Biodiversitas, Belo Horizonte.

WILCOVE, D.S.1985. Nest predation in forest tracts and the decline of migratory songbirds. Ecology 66(4):1211-1214. http://dx.doi. org/10.2307/1939174

WILSON, E.O. 1975. Sociobiology: the new synthesis. Belknap Press of Harvard University Press, Cambridge. 